\title{
Evaluation of Achillea, Matricaria, and Anthemis plants following selection for drought tolerance at seedling stages
}

\author{
Parvin Salehi Shanjani ${ }^{1 *}$, Leila Rasoulzadeh, Hamideh Javadi
}

\author{
Natural Resources Gene Bank, Research Institute of Forests and Rangelands, \\ Agricultural Research, Education and Extension Organization, P.O.Box 13185-116, Tehran, Iran
}

\begin{abstract}
Salehi Shanjani, P., Rasoulzadeh, L., Javadi, H., 2022. Evaluation of Achillea, Matricaria, and Anthemis plants following selection for drought tolerance at seedling stages. Folia Oeologica, 49 (1): 80-91.

The genetic potentials of eight species of Achillea (A. millefolium, A. fillipendulla, A. biebersteinii, A. nobilis, A. eriophora), Matricaria (M. ricotita), and Anthemis (An. haussknechtii and An. tinctoria) under drought conditions during the seedling stage were measured. Non-ionic water-soluble polymer polyethylene glycol (PEG, molecular weight 6000) was used to simulate water stress at five osmotic potential levels $(0,-0.3$, $-0.6,-0.9$, and $-1.2 \mathrm{MPa}$ ). An acceptable threshold value for germination was osmotic potential $-0.6 \mathrm{MPa}$, and the modest osmotic potential was $-1.2 \mathrm{MPa}$ for studied taxa. Seedlings of germinated at two control and osmotic potential - 0.6 $\mathrm{MPa}$ (as an acceptable threshold value for germination) treatments were sowed in a field under rainfed conditions. Genetic differentiation of control plants (CP) versus early selected plants (ESP, germinated at osmotic potential -0.6 MPa) was studied using morphological, physiological, and molecular (ISSR) markers. No significant differences were observed between morphological traits of CP and ESP in all species, however, days to full flowering shortened in ESP. The physiological results demonstrate that under rainfed conditions, the ESP, in a quick response, collect osmolytes and amplify the activity of antioxidative enzymes to survive drought. The genetic relationship in the group of genotypes, that ISSR marker set it out, is affiliated to taxon even though AMOVA showed a partial differentiation between CP and ESP groups (21\%). It was concluded that the selection of tolerating individuals at the seedling stage represents a likely positive strategy to have higher drought tolerance feature in plants under rainfed conditions.
\end{abstract}

\section{Keywords}

antioxidative enzymes, osmolytes, PEG, rainfed conditions

\section{Introduction}

Arid and semi-arid zones constitute more than $82 \%$ of Iran's territory and its various regions struggle with water shortage and drought (EMADODIN et al., 2019). Plant growth and crop productivity are affected by water constraints as one of the main environmental problems. To face the problem, the selection of drought-tolerant species and varieties seems the favorable economic approach to help exploitation and rehabilitation of mentioned regions (LoBELL et al., 2014).

Achillea and Anthemis are the important genera of the Asteraceae family and individual species grow wild in different parts of Iran (GHANI et al., 2009). Due to

\footnotetext{
*Corresponding author:

e-mail: psalehi@rifr-ac.ir; psalehi1@gmail.com 
over-collection, essentially in the flowering period, land conversion, and also land degradation, the Achillea, and Anthemis species are now considered at risk for local extinction, which in turn affects financial income and subsequently livelihood of the local human population. Many healers recognized that recently the species become very scarce and to ensure the sustainable utilization to meet the growing demand of these wild species, it has become necessary to develop rapid methods of their commercial cultivation (SALEHI SHANJANi et al., 2014) as well as the selection of drought-tolerant species and varieties (FAHAD et al., 2017).

There are various methods to screen plant genotypes at the seedling stage to determine their drought tolerance (SuzUKi et al., 2014). Bilal et al. (2015) suggested root to shoot ratio as well as relative water content as their selection criteria in wheat regarding drought tolerance. AlmESELMANi et al. (2011) preferred relative water content (RWC) as a good criterion for the selection of droughttolerant wheat varieties at the seedling stage. RWC in terms of its relationship with the volume of a cell can correctly show the balance between water absorbed by the plant and disbursed through transpiration (ARJENAKI et al., 2012). DATTA et al. (2011) applied both normal and water-deficient conditions to wheat genotypes and noticed that genotypes with "optimum RWC and root and shoot length" performed better under environments which means they were considered drought-tolerant genotypes. With the presence of an additive gene effect across environments, survived seedlings at drought conditions may express moderate-to-high viability (AHMED et al., 2019).

The experiment herein was directed to evaluate the early selection effect of eight species of Achillea ( $A$. millefolium, A. fillipendulla, A. biebersteinii, A. nobilis, A. eriophora), Matricaria (M. ricotita), and Anthemis (An. haussknechtii and An. tinctoria) regarding their genetic potential to drought tolerance at rainfed conditions, to define the differences between control and early selected (by osmotic potential $-0.6 \mathrm{MPa}$ treatment) plants using morphological, physiological and molecular (ISSR) markers. This will contribute a clear perspective on drought tolerance in dryland farming areas in semiarid and rainfed regions.

\section{Materials and methods}

Seed materials of eight species of Achillea (A. millefolium, A. fillipendulla, A. biebersteinii, A. nobilis, A. eriophora), Matricaria (M. ricotita), and Anthemis (An. haussknechtii and An. tinctoria) were provided by the Natural Resources Gene Bank of Iran.

Germination assays were performed by evenly distributing the seeds in a $10 \mathrm{~cm}$ diameter sterile Petri dish and to mimic drought stress, two layers of filter paper saturated with $8 \mathrm{ml}$ of treatment were used (Li et al., 2013). Polyethylene glycol-6000 (PEG 6000) at five concentrations $(0,5,10,15$, and $20 \%)$ used to generate five osmotic potential levels $(0,-0.3,-0.6,-0.9$, and $-1.2 \mathrm{MPa}$, respectively); 0 osmotic potential served as the control. Five replicates of 50 seeds of each osmotic potential were used to assess the germination percentage.

Germinated seedlings at two control and osmotic potential $-0.6 \mathrm{MPa}$ (as a threshold value for the favorable germination) treatments were sowed and the following traits were analyzed: plant height $(\mathrm{cm})$, stem diameter $(\mathrm{mm})$, leaf length $(\mathrm{cm})$, leaf width $(\mathrm{cm})$, leaf length to width ratio, number of flowering stems, capitulate no., inflorescence diameter $(\mathrm{cm})$, inflorescence length $(\mathrm{cm})$, inflorescence width $(\mathrm{cm})$, inflorescence length to width ratio, fresh weight $(\mathrm{g})$, dry weight $(\mathrm{g})$ and days to flowering $(50 \%)$.

In this study relative water content (RWC \%, YAMASAKI et al., 1999), dry matter percentage (DM \%, YAMASAKI et al., 1999), soluble proteins ( $\mu \mathrm{g} \mathrm{g}^{-1} \mathrm{DW}$, BRADFORD, 1976), proline content ( $\mathrm{mg} \mathrm{g}^{-1} \mathrm{DW}$, BATEs et al., 1973), soluble sugar ( $\mathrm{mg} \mathrm{g}^{-1} \mathrm{DW}$, YEMM and WiLlis, 1954), peroxidases activity (Abs.min ${ }^{-1} \mathrm{~g}^{-1}$ DW, Fu and HuANG, 2001), polyphenol oxidases activity (Abs. $\mathrm{min}^{-1} \mathrm{~g}^{-1} \mathrm{DW}, \mathrm{Fu}$ and HuANG, 2001), chlorophyll a ( $\mathrm{mg} \mathrm{g}^{-1}$ DW, LiCHTENTHALER, 1987), chlorophyll b (mg g-1 DW, LichtenthaLeR, 1987), carotenoids (mg g-1 DW, LichtenthaLER, 1987) were analyzed in eight Achillea, Matricaria and Anthemis species. Plant materials were collected from the youngest fully expanded leaves in five replicates of both control plants (CP) and early selected plants (ESP, germinated at osmotic potential $-0.6 \mathrm{MPa}$ ) during midday in the research field.

In total, 160 samples from both CP and ESP in eight Achillea, Matricaria, and Anthemis species were analyzed. Polymerase chain reaction (PCR) was conducted according to ZIETKIEWICZ et al. (1994). 15 ISSR primers were initially screened but only six primers were used in the analysis (Table 1). The clear and reproducible banding patterns generated were used to evaluate genetic variation. The reaction conditions were optimised and mixtures were composed of $20 \mathrm{ng}$ of DNA, $10 \times$ buffer $(20 \mathrm{mM}$ Tris$\mathrm{HCl} \mathrm{pH} 8.4 ; 50 \mathrm{mM} \mathrm{KCl}$ ), $1 \mathrm{U}$ TaqDNA polymerase, 2 $\mathrm{mM} \mathrm{MgCl}, 0.2 \mathrm{mM} \mathrm{dNTP}$, and $0.8 \mu \mathrm{M}$ primer. The PCR amplification protocol includes one cycle for $5 \mathrm{~min}$ at 94 ${ }^{\circ} \mathrm{C}$ and then is followed by 42 cycles for $30 \mathrm{sec}$ at $94{ }^{\circ} \mathrm{C}$, $1 \mathrm{~min}$ at $51-53{ }^{\circ} \mathrm{C}$ (Table 1 ), $1 \mathrm{~min}$ at $72{ }^{\circ} \mathrm{C}$ and $5 \mathrm{~min}$ for final extension at $72{ }^{\circ} \mathrm{C}$. Amplification productions (10 $\mu \mathrm{L}$ ) are mixed with $5 \mu \mathrm{L}$ bromophenol blue separated on $1.5 \%$ agarose gel and marked with $5 \mu \mathrm{L}$ of SYBR Green and then photographed.

\section{Data analysis}

To determine differences among species and treatments for each variable, all data were subjected to the two-way analysis of variance (ANOVA) with species and drought treatments as factors. Using Duncan's test at $\mathrm{P}<0.01$ level showed significant differences between means. The normality of data was tested by the Kolmogorov-Smirnov test. Where necessary, data were transformed to match the assumptions of ANOVA. Statistical tests were performed with Minitab 16. 
Table 1. List of primers and their nucleotide sequences, annealing temperature, number of observed bands, and the percentage of polymorphism produced by ISSR markers

\begin{tabular}{|c|c|c|c|c|}
\hline Primer code & Sequence $5^{\prime}-3^{\prime}$ & $\begin{array}{l}\text { Annealing } \\
\text { temperature }\left({ }^{\circ} \mathrm{C}\right)\end{array}$ & $\mathrm{Nb}$ & $\mathrm{P} \%$ \\
\hline ISSR 7 & CACACACACACAGT & 53 & 10 & 40 \\
\hline ISSR 3 & СТСТСТСТСТСТСТСТТG & 53 & 10 & 22.50 \\
\hline ISSR 19 & AGAGAGAGAGAGAGGT & 52 & 6 & 43 \\
\hline P 26 & ССАСТСТСТСТСТСТСТСТ & 51 & 19 & 37.50 \\
\hline P 5 & ACACACACACACACACG & 52 & 6 & 33.33 \\
\hline P 12 & GAGAGAGAGAGAGAGAT & 52 & 8 & 4 \\
\hline
\end{tabular}

$\mathrm{Nb}$, number of bands; $\mathrm{P} \%$, percentage of polymorphic bands.

Considering binary data, amplification reactions from all individuals were scored and then GENALEX 6.5 software was used to calculate genetic variation statistics (Peakall \& Smouse 2006). The number of observed and private bands (number of bands unique to a single population), mean number of alleles $(\mathrm{Na})$, expected heterozygosity $(\mathrm{He})$, and percentage of polymorphic loci (P \%) were evaluated according to NEI (1978). According to NeI's method (1978), the genetic distances were calculated and the distance matrix was subjected to principal coordinate analysis (PCoA) (MONFARED et al. 2018). The SIMJACARD code of the software package NTSYS-pc: 2.11 was used to estimate pairwise genetic similarity (RoHLF, 2004). A similarity matrix based on the unweighted pair group method and arithmetic means (UPGMA) was generated using Jaccard's similarities and SHAN of NTSYS-pc to construct the dendrogram of all the 160 genotypes. Cophenetic matrices were calculated for characterising the correlations between the dendrograms and similarity matrices.

\section{Results}

Analysis of variance of germination parameters data showed highly significant differences among species, treatments, and the interaction between species and treatment (Table 2). Mean estimate of almost all seedling traits of A. millefolium, A. fillipendulla, A. biebersteinii, A. nobilis, A. eriophora, M. ricotita, An. haussknechtii, An. tinctoria decreased under osmotic potential simulated by PEG (Table 3 ). The seed germination was more often and strenuously under control and osmotic potential -0.3 $\mathrm{MPa}$ than PEG -0.6 and $-0.9 \mathrm{MPa}$. At osmotic potential $-0.6 \mathrm{MPa}$, a notable decline in the germination percentage was recorded that indicated osmotic potential $-0.6 \mathrm{MPa}$ is considered a threshold value for the favorable germination of Achillea, Matricaria, and Anthemis seeds. Conversely, no seeds germinated at the osmotic potential $-1.2 \mathrm{MPa}$, which indicated that osmotic potential $-1.2 \mathrm{MPa}$ is the lowest osmotic potential for Achillea, Matricaria, and Anthemis germination. Root to shoot length ratio for tested species varied significantly, under different levels of water deficit (Fig. 1).

Seedlings of germinated at two control and osmotic potential $-0.6 \mathrm{MPa}$ (as a threshold value for the favorable germination) treatments were sowed in a field under rainfed conditions. Analysis of variance of the growth characteristics data showed highly significant differences among species (Table 4). However, the drought treatment in genotypes has a significant effect on plant height, stem number, leaf length, and leaf length to width ratio, capitule number, inflorescence length and width. The

Table 2. Analysis variance of germination parameters

\begin{tabular}{lcrllllll}
\hline SOV & d.f. & $\begin{array}{l}\text { Germination } \\
\%\end{array}$ & $\begin{array}{l}\text { Germination } \\
\text { rate }\end{array}$ & $\begin{array}{l}\text { Seed vigor } \\
\text { index }\end{array}$ & $\begin{array}{l}\text { Seedling dry } \\
\text { weight } \\
(\mathrm{g})\end{array}$ & $\begin{array}{l}\text { Shoot } \\
\text { length } \\
(\mathrm{mm})\end{array}$ & $\begin{array}{l}\text { Root } \\
\text { length } \\
(\mathrm{mm})\end{array}$ & $\begin{array}{l}\text { Root to } \\
\text { shoot } \\
\text { ratio }\end{array}$ \\
\hline $\begin{array}{l}\text { Species } \\
\text { Treat }\end{array}$ & 7 & $7,055.23^{* *}$ & $399.186^{* *}$ & $268.81^{* *}$ & $0.00000078^{*}$ & $58.54^{* *}$ & $370.24^{* *}$ & $\begin{array}{l}1.65^{* *} \\
2.278^{* *}\end{array}$ \\
$\begin{array}{l}\text { Species } \\
\text { treat }\end{array}$ & 21 & $134.98^{* *}$ & $32.90^{* *}$ & $35.52^{* *}$ & $0.0000122^{* *}$ & $11.12^{* *}$ & $49.38^{* *}$ & $0.5625^{* *}$ \\
Error & 64 & 36.66 & $3.38^{*}$ & 7.284 & 0.00000033 & 4.56 & 20.65 & 0.3164 \\
\hline $\mathrm{CV} \%$ & & 11.00 & 18.18 & 20.64 & 27.84 & 22.89 & 28.31 & 32.19 \\
\hline
\end{tabular}

*, ** significant at 0.05 and 0.01 levels, respectively; SOV, source of variation; d.f., degrees of freedom. 
Table 3. The effect of different osmotic potential levels $(0,-0.3,-0.6$, and $-0.9 \mathrm{MPa})$ on the germination parameters of the studied species

\begin{tabular}{|c|c|c|c|c|c|c|c|}
\hline Species & Treat & $\begin{array}{l}\text { Germination } \\
\%\end{array}$ & $\begin{array}{l}\text { Germination } \\
\text { rate }\end{array}$ & $\begin{array}{l}\text { Seed vigor } \\
\text { index }\end{array}$ & $\begin{array}{l}\text { Seedling dry } \\
\text { weight } \\
\text { (g) }\end{array}$ & $\begin{array}{l}\text { Shoot } \\
\text { length } \\
(\mathrm{mm})\end{array}$ & $\begin{array}{l}\text { Root length } \\
(\mathrm{mm})\end{array}$ \\
\hline \multirow{4}{*}{ A. millefolium } & 0 & $92 \mathrm{a}$ & $22.69 \mathrm{a}$ & $25.72 \mathrm{a}$ & $0.029 \mathrm{a}$ & $11.7 \mathrm{a}$ & $17.8 \mathrm{a}$ \\
\hline & -0.3 & $82 b$ & $18.16 \mathrm{~b}$ & $22.2 b$ & $0.025 \mathrm{~b}$ & $9.3 b$ & $16.8 \mathrm{ab}$ \\
\hline & -0.6 & $41 \mathrm{c}$ & $11.11 \mathrm{c}$ & $15.78 \mathrm{c}$ & $0.019 \mathrm{c}$ & $8.7 \mathrm{bc}$ & $16.3 \mathrm{ab}$ \\
\hline & -0.9 & $20.5 \mathrm{~d}$ & $5.5 \mathrm{~d}$ & $9.37 \mathrm{~d}$ & $0.015 \mathrm{~d}$ & $6.7 \mathrm{c}$ & $15.9 \mathrm{ab}$ \\
\hline \multirow{4}{*}{ A. fillipendulla } & 0 & $98 \mathrm{a}$ & $19.7 \mathrm{a}$ & $25.57 \mathrm{a}$ & $0.096 \mathrm{a}$ & $9.1 \mathrm{a}$ & $22.1 \mathrm{a}$ \\
\hline & -0.3 & $83 b$ & $14.83 b$ & $20.94 b$ & $0.032 \mathrm{~b}$ & $8.9 \mathrm{ab}$ & $17.73 b$ \\
\hline & -0.6 & $43 c$ & $8.45 c$ & $12.91 \mathrm{c}$ & $0.02 \mathrm{c}$ & $8.73 a b$ & $14 \mathrm{bc}$ \\
\hline & -0.9 & $22 d$ & $3.87 \mathrm{~d}$ & $11.54 \mathrm{c}$ & $0.013 \mathrm{c}$ & $7.57 \mathrm{~b}$ & $12.3 \mathrm{c}$ \\
\hline \multirow{4}{*}{ A. biebersteinii } & 0 & $94 a$ & $22.47 \mathrm{a}$ & $24.23 \mathrm{a}$ & $0.077 \mathrm{a}$ & $7.69 a$ & $19.44 \mathrm{a}$ \\
\hline & -0.3 & $89 b$ & $17.76 \mathrm{~b}$ & $19.85 b$ & $0.027 \mathrm{~b}$ & $7.53 \mathrm{a}$ & $14 \mathrm{~b}$ \\
\hline & -0.6 & $46 c$ & $9.09 \mathrm{c}$ & $13.58 \mathrm{c}$ & $0.011 \mathrm{c}$ & $6.27 \mathrm{~b}$ & $13.33 b$ \\
\hline & -0.9 & $23 d$ & $4.62 \mathrm{~d}$ & $7.3 \mathrm{~d}$ & $0.008 \mathrm{c}$ & $5.93 b$ & $9.22 \mathrm{c}$ \\
\hline \multirow{4}{*}{ A. nobilis } & 0 & $89 a$ & $23.02 \mathrm{a}$ & $20.78 \mathrm{a}$ & $0.031 \mathrm{a}$ & $8.15 \mathrm{a}$ & $19.02 \mathrm{a}$ \\
\hline & -0.3 & $83 b$ & $18.11 \mathrm{~b}$ & $20.63 a$ & $0.021 \mathrm{~b}$ & $7.93 \mathrm{a}$ & $18.56 \mathrm{ab}$ \\
\hline & -0.6 & $46 c$ & $9.77 \mathrm{c}$ & $17.81 \mathrm{~b}$ & $0.015 \mathrm{c}$ & $7.93 a$ & $15.44 \mathrm{~b}$ \\
\hline & -0.9 & $22 d$ & $5.43 d$ & $11.43 \mathrm{c}$ & $0.009 \mathrm{~d}$ & $6.53 b$ & $15.33 b$ \\
\hline \multirow{4}{*}{ A.eriophora } & 0 & $81 \mathrm{a}$ & $16.81 \mathrm{a}$ & $20.44 a$ & $0.119 \mathrm{a}$ & $10.07 \mathrm{a}$ & $15.47 \mathrm{ab}$ \\
\hline & -0.3 & $72 b$ & $7.6 \mathrm{~b}$ & $16.37 \mathrm{~b}$ & $0.029 \mathrm{~b}$ & $8.73 b$ & $17.6 \mathrm{a}$ \\
\hline & -0.6 & $33 \mathrm{c}$ & $4.47 \mathrm{c}$ & $8.41 \mathrm{c}$ & $0.021 \mathrm{~b}$ & $6.67 \mathrm{c}$ & $13.07 \mathrm{~b}$ \\
\hline & -0.9 & $20 \mathrm{~d}$ & $1.43 \mathrm{~d}$ & $2.6 \mathrm{~d}$ & $0.011 \mathrm{c}$ & $6.75 c$ & $6.23 \mathrm{c}$ \\
\hline \multirow{4}{*}{ An. haussknechtii } & 0 & $36 \mathrm{a}$ & $3.79 \mathrm{a}$ & $11.76 \mathrm{a}$ & $0.028 \mathrm{a}$ & $15.68 \mathrm{a}$ & $23.56 \mathrm{a}$ \\
\hline & -0.3 & $22 b$ & $1.57 \mathrm{~b}$ & $8.16 \mathrm{~b}$ & $0.021 \mathrm{~b}$ & $13.07 \mathrm{ab}$ & $18.66 \mathrm{~b}$ \\
\hline & -0.6 & $9 \mathrm{c}$ & $0.57 \mathrm{c}$ & $2.79 \mathrm{c}$ & $0.020 \mathrm{~b}$ & $10.26 \mathrm{~b}$ & $16.96 \mathrm{~b}$ \\
\hline & -0.9 & $3.5 \mathrm{~d}$ & $0.19 \mathrm{~d}$ & $0.66 \mathrm{~d}$ & $0.011 \mathrm{c}$ & $8.44 \mathrm{c}$ & $10.11 \mathrm{c}$ \\
\hline \multirow{4}{*}{ An. tinctoria } & 0 & $32 \mathrm{a}$ & $2.98 \mathrm{a}$ & $15.15 \mathrm{a}$ & $0.024 \mathrm{a}$ & $17.6 \mathrm{a}$ & $29.73 a$ \\
\hline & -0.3 & $26 \mathrm{~b}$ & $1.49 \mathrm{~b}$ & $5.37 \mathrm{~b}$ & $0.012 b$ & $12.39 \mathrm{~b}$ & $21.63 b$ \\
\hline & -0.6 & $8 \mathrm{c}$ & $0.77 \mathrm{c}$ & $2.71 \mathrm{c}$ & $0.02 \mathrm{c}$ & $11.33 \mathrm{~b}$ & $22.5 b$ \\
\hline & -0.9 & $6 c$ & $0.39 \mathrm{c}$ & $1.31 \mathrm{c}$ & $0.02 \mathrm{c}$ & $7.33 c$ & $16.83 \mathrm{c}$ \\
\hline \multirow{4}{*}{ M. ricotita } & 0 & $86 a$ & $18.285 \mathrm{a}$ & $21.34 \mathrm{a}$ & $0.033 \mathrm{a}$ & $12.13 \mathrm{a}$ & $22.465 \mathrm{a}$ \\
\hline & -0.3 & $78.4 \mathrm{~b}$ & $17.815 b$ & $22.27 \mathrm{a}$ & $0.025 \mathrm{~b}$ & $10.9 \mathrm{~b}$ & $17.6 \mathrm{~b}$ \\
\hline & -0.6 & $32 \mathrm{c}$ & $10.67 \mathrm{c}$ & $16.45 \mathrm{~b}$ & $0.021 \mathrm{c}$ & $9.6 \mathrm{~b}$ & $16.7 \mathrm{~b}$ \\
\hline & -0.9 & $22 d$ & $5.67 \mathrm{~d}$ & $10.97 \mathrm{c}$ & $0.012 \mathrm{~d}$ & $7.43 c$ & $16.035 b$ \\
\hline
\end{tabular}

interaction between species and treatments was significant in leaf length to width ratio, inflorescence length, and inflorescence length to width ratio (Table 4). Comparison of the average evaluated traits using Duncan's test showed the amount of most traits was not significantly different between CP and ESP of each Achillea, Matricaria and
Anthemis species (Table 5). The exceptional trait was days to full flowering $(50 \%)$ that was shortened in ESP in all species.

Analysis of variance of different physiological traits of genotypes in the field under rainfed conditions showed highly significant differences among species 


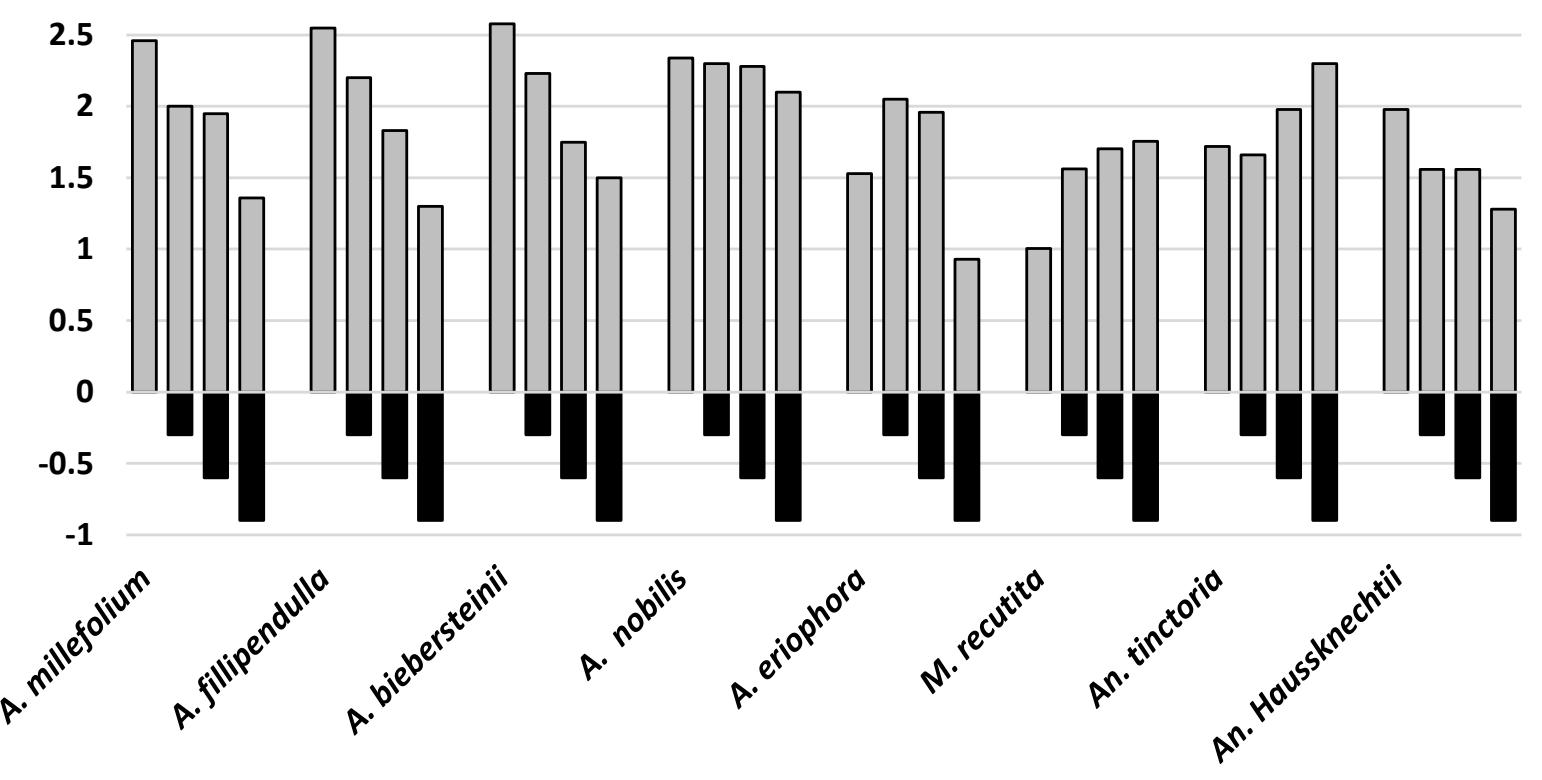

Osmotic potential levels $(0,-0.3,-0.6$ and $-0.9 \mathrm{MPa}) \quad \square$ Root to shoot lenght ratio

Fig. 1. The effect of different osmotic potential levels $(0,-0.3,-0.6$, and $-0.9 \mathrm{MPa})$ on the root to shoot length ratio of studied species.

except for RWC \% and soluble proteins (Table 6). DM $\%$, soluble protein, soluble sugar, proline content, and amount of chlorophyll a, chlorophyll b, and carotenoids were significantly different in treatments. The interaction between species and treatments were significant in proline content, and amount of chlorophyll a, chlorophyll b, and carotenoids (Table 6). Mean comparison of different physiological traits between CP versus ESP in a field under rainfed conditions indicated a significantly higher amount of total soluble proteins, soluble sugars, proline content (except A. fillipendulla), and DM \% (except A. millefolium) in ESP almost in all species (Table 7). However, differences in enzyme activity in CP versus ESP were not the same in the studied species. Peroxidase activity was significantly lower in ESP of Achillea species (A. millefolium, A. fillipendulla, A. biebersteinii, and A. nobilis), however in A. eriophora, An. haussknechtii and An. tinctoria was higher. No significant differentiation was found in polyphenol oxidases activity in CP and ESP of studied species. The amount of RWC was not different in CP and ESP of the species except An. tinctoria that was higher in CP plants. The amount of chlorophyll a, chlorophyll $\mathrm{b}$, and carotenoids was significantly higher in ESP of Anthemis species, however, the amount of the pigments did not follow a similar trend in Achillea and Matricaria species (Table 7).

Of the 15 ISSR primers analyzed in this study, six showed polymorphism (Table 8). The range number of polymorphic fragments was from 6 to 19, with an average of 10.2 per primer. Genetic variation statistics from across all analyzed species are presented in Table 8 . In the pooled samples of An. haussknechtii (47\%) high band polymorphism was discovered. Comparing the eight taxa, An. haussknechtii (18.4\%) showed higher genetic diversity statistics ( $\mathrm{He}$ ). Of five Achillea species, A. millefolium showed higher $\mathrm{He}(12.6 \%)$. Results showed no trend in the genetic diversity of CP versus ESP (Table 8). In other words, the selection of germinated seeds under treatment PEG $-0.6 \mathrm{MPa}$ did not reduce the diversity parameters of the analyzed ISSR markers.

To interpret relationships among the genotypes of different species, results of principal component analyses (PCoA) using the ISSR data are presented in Fig. 2. A total of $84 \%$ variation was assigned to the first three components of PCoA. The first principal coordinate accounted for $61 \%$ of the total variation and the Achillea species was separated from the Anthemis and Matricaria species (Fig. 2). Anthemis and Matricaria species were partially distinguished from each other across the second PCoA, which explained $13 \%$ of the total variation. The $\mathrm{CP}$ and ESP of studied species were partially separated. Results of the AMOVA indicated that $28 \%$ of the genetic variation occurred between species, $21 \%$ between $\mathrm{CP}$ and ESP groups, and most of the variation occurred within $\mathrm{CP}$ and ESP groups.

\section{Discussion}

The lack of adequate moisture leading to water stress is a common occurrence in rainfed areas, brought about by infrequent rains and poor irrigation that may prevent plants from performing their maximum potential performance and can threaten their survival (WANG et al., 2005). The plant 


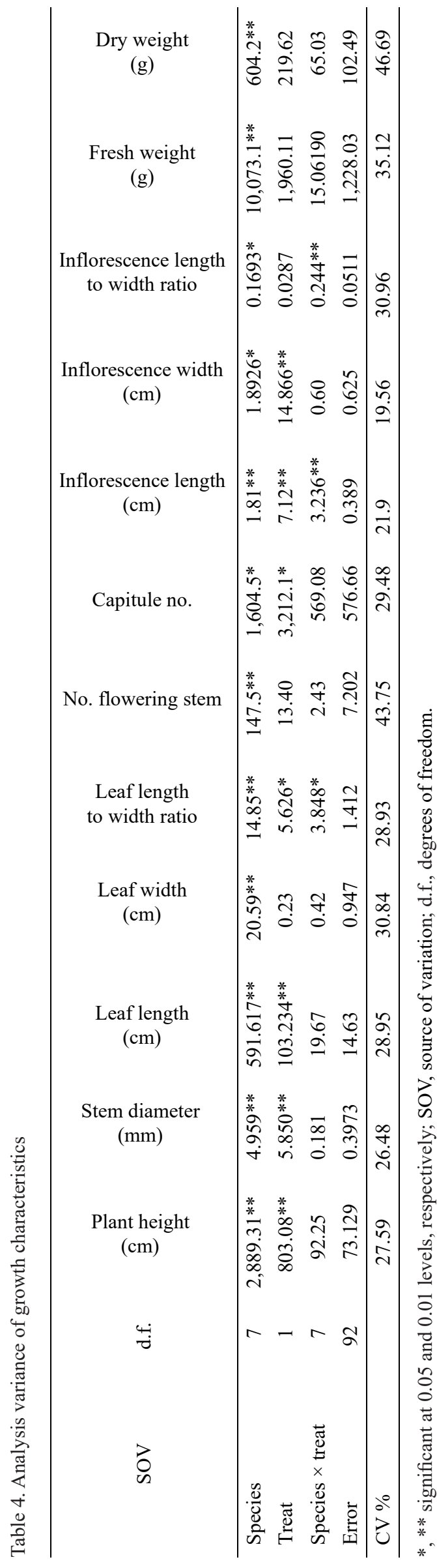

genotypes with the best performance under water stress environments could increase the production of rainfed areas (AHmed et al., 2017). The selection at the seedling stage is one of the common methods for the creation of drought-tolerant genotypes. Survived seedlings at drought conditions may expose moderate-to-high viability with an additive gene effect across environments (AHMED et al., 2019). For the selection of drought-tolerant genotypes at the seedling stage, it is essential to primarily understand the response of seedlings in water-deficient conditions.

The expression of mean performance almost for all seedling traits of $A$. millefolium, A. fillipendulla, $A$. biebersteinii, A. nobilis, A. eriophora, M. ricotita, An. haussknechtii, An. tinctoria decreased under osmotic potential simulated by PEG. A reducing pattern in germination parameters was reported in Achillea (A. eriophora, A. millefolium, A. filipendula, A. nobilis, A. wilhelmsii and A. biebersteinii), Matricaria, and Anthemis species (Ghani et al., 2009; Salehi Shanjani et al., 2014; QARI, 2017). Present results indicated that osmotic potential $-1.2 \mathrm{MPa}$ is the threshold for studied species to germinate and $-0.6 \mathrm{MPa}$ is the threshold to germinate well. Compared to some desert plants, the thresholds of good germination among Periploca sepium, Elaeagnus angustifolia, and Caragana korshinskii were $-1.2 \mathrm{MPa}$ (Sun et al., 2011), and for Eremosparton songoricum -0.9 MPa (Li et al., 2013), which was lower than the present results for studied species. The results implied that the seeds of the studied species require a middle water demand for good germination, as it was observed that the seeds did not germinate under heavy drought stress. This amount of moisture requirement reflects the limited ability of studied species to resist harsh drought stress during the germination stage. According to the results, the seedlings germinated under osmotic potential $-0.6 \mathrm{MPa}$ were tolerant to water stress compared to the control treatment.

The study of growth and development of studied species in a field under rainfed conditions indicated almost no differences between CP versus ESP. The except trait was the number of days to full flowering $(50 \%)$ that was shortened in ESP of all studied species. The result of early selection was promising because early flowering time and a shorter vegetative phase (drought escape) enabled plants to complete a full life cycle before a future drought event. Among populations of native plants that have a long period of evolution, largely among perennial species, this strategy has a broad usage, but also in some annual grasses. Under the current conditions of changing climate, natural selection favors early flowering time plants to become likely adapted to the future drought (KoOYERS, 2015). It was suggested that the results hold for the wild annual species Avena barbata (SHERRARD and MAHERALI, 2006), as well as 279 other species examined and reported by PARMESAN and YOHE (2003). It was confirmed that these species are likely to flower earlier in warmer regions. Many efforts were also conducted to develop early flowering crops, which have a strong genetic background. Plants having early flowering can control vegetative growth via artificial selection by breeders and therefore their reproductive growth takes place before the terminal stress. This mediating process 


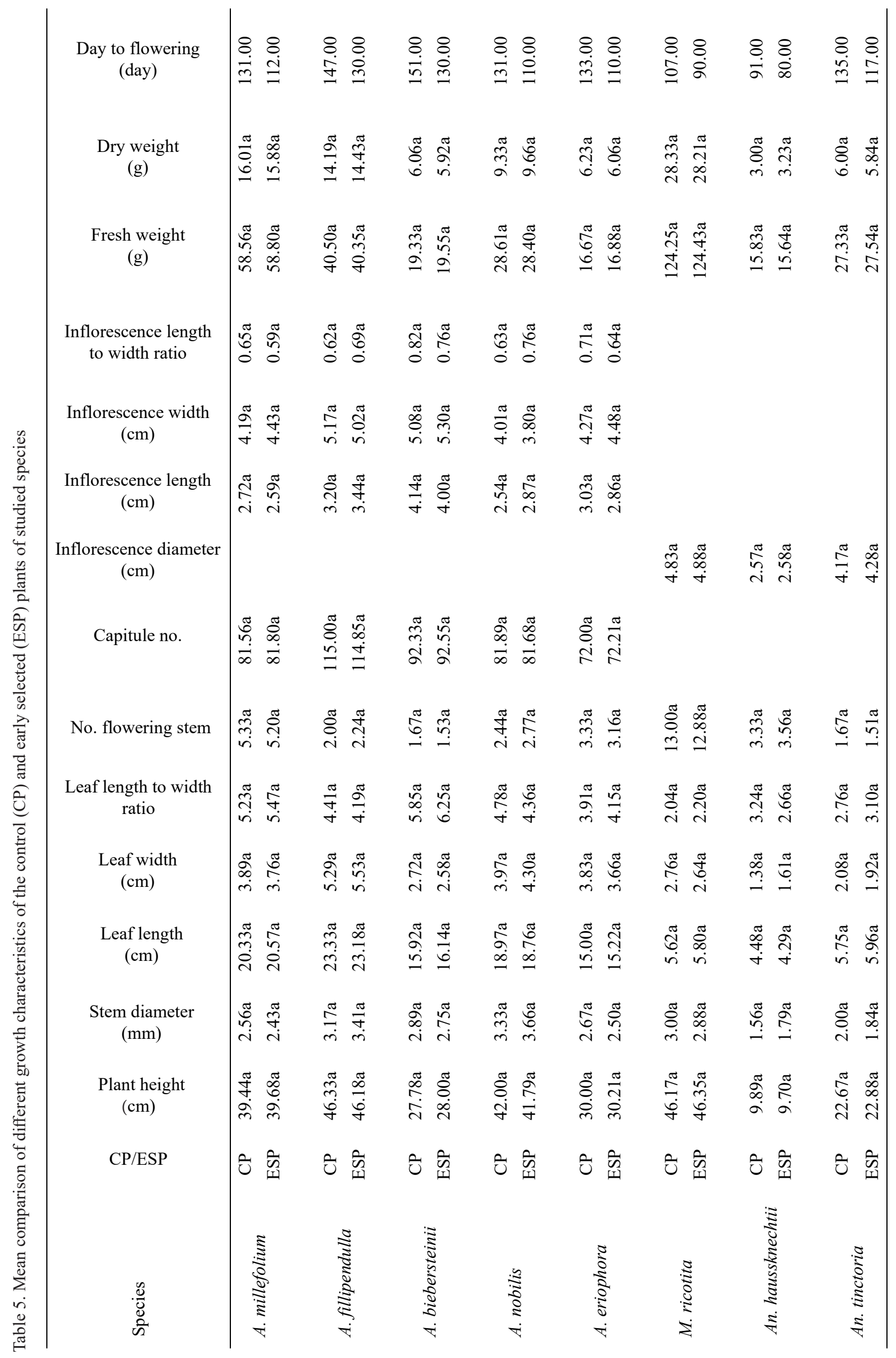


Table 6. Analysis variance of different physiological characteristics

\begin{tabular}{|c|c|c|c|c|c|c|c|c|c|c|c|}
\hline SOV & d.f. & 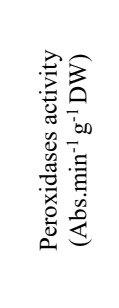 & 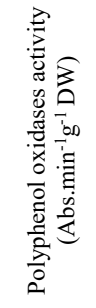 & $\grave{j}_{\approx}^{\circ}$ & $\sum_{a}^{\circ}$ & 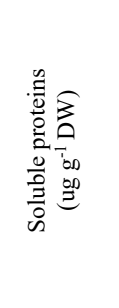 & 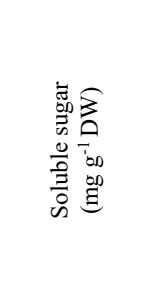 & 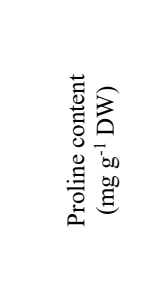 & 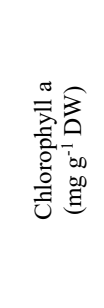 & 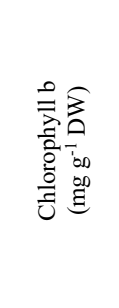 & 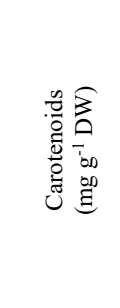 \\
\hline Species & 7 & $253.69^{* *}$ & $2.37 * *$ & 39.37 & $85.15^{* *}$ & 60.47 & $2,308.38^{* *}$ & $143,070.20^{* *}$ & $0.035 * *$ & $0.057^{* *}$ & $0.0072 * *$ \\
\hline Treat & 1 & 0.211 & 0.599 & 34.97 & $317.03^{* * *}$ & $1,129.1 * *$ & $12,258.08 * *$ & $615,163.33 * *$ & $0.267 * *$ & $0.270 * *$ & $0.1208^{* *}$ \\
\hline $\begin{array}{l}\text { Species } \\
\times \text { treat }\end{array}$ & 7 & 76.46 & 0.612 & 13.85 & 19.89 & 55.47 & 986.00 & $38,789.53^{*}$ & $0.022 *$ & $0.0147^{*}$ & $0.0066^{* *}$ \\
\hline Error & 128 & 31.21 & 0.571 & 23.45 & 16.17 & 56.41 & 822.66 & $30,695.77$ & 0.00443 & 0.0073 & 0.00188 \\
\hline $\mathrm{CV} \%$ & & 31.99 & 13.26 & 6.52 & 20.24 & 37.3 & 33.94 & 36.66 & 8.25 & 23.5 & 11.45 \\
\hline
\end{tabular}

*, ** significant at 0.05 and 0.01 levels, respectively; SOV, source of variation; d.f., degrees of freedom.

Table 7. Mean comparison of different physiological characteristics of the control (CP) and early selected (ESP) plants of studied species

\begin{tabular}{|c|c|c|c|c|c|c|c|c|c|c|c|}
\hline Species & 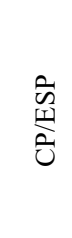 & 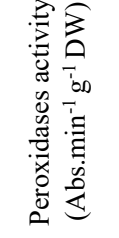 & 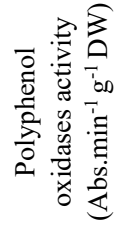 & 递 & $\sum_{0}^{\circ}$ & 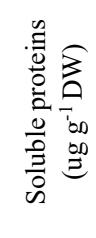 & 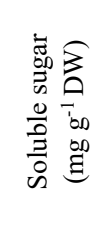 & 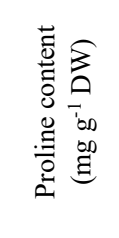 & 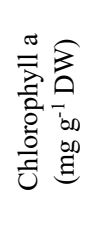 & 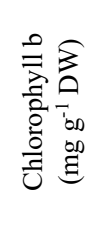 & 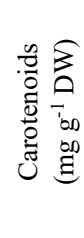 \\
\hline \multirow{2}{*}{ A. millefolium } & $\mathrm{CP}$ & $19.53 \mathrm{a}$ & $6.07 \mathrm{a}$ & $75.19 \mathrm{a}$ & $20.65 \mathrm{a}$ & $14.98 b$ & $32.54 b$ & $80.44 b$ & $0.78 \mathrm{a}$ & $0.32 \mathrm{a}$ & $0.36 \mathrm{a}$ \\
\hline & ESP & $14.97 \mathrm{~b}$ & $5.81 \mathrm{a}$ & $77.54 \mathrm{a}$ & $21.7 \mathrm{a}$ & $23.9 \mathrm{a}$ & $47.12 \mathrm{a}$ & $296.28 \mathrm{a}$ & $0.83 a$ & $0.37 \mathrm{a}$ & $0.40 \mathrm{a}$ \\
\hline \multirow{2}{*}{ A. fillipendulla } & $\mathrm{CP}$ & $12.78 \mathrm{a}$ & $4.62 \mathrm{a}$ & $75.27 \mathrm{a}$ & $20.57 b$ & $13.50 \mathrm{~b}$ & $40.43 b$ & $100.06 \mathrm{a}$ & $0.85 \mathrm{a}$ & $0.48 \mathrm{a}$ & $0.39 \mathrm{a}$ \\
\hline & ESP & $9.99 \mathrm{~b}$ & $5.29 \mathrm{a}$ & $76.25 \mathrm{a}$ & $23.06 \mathrm{a}$ & $25.82 \mathrm{a}$ & $50.3 \mathrm{a}$ & $101.6 \mathrm{a}$ & $0.87 \mathrm{a}$ & $0.49 \mathrm{a}$ & $0.41 \mathrm{a}$ \\
\hline \multirow{2}{*}{ A. biebersteinii } & $\mathrm{CP}$ & $15.02 \mathrm{a}$ & $5.8567 \mathrm{a}$ & $73.21 \mathrm{a}$ & $19.902 b$ & $22.38 b$ & $29.25 b$ & $21.2 \mathrm{~b}$ & $0.78 \mathrm{~b}$ & $0.31 \mathrm{~b}$ & $0.35 \mathrm{a}$ \\
\hline & ESP & $11.722 b$ & $5.6117 \mathrm{a}$ & $74.41 \mathrm{a}$ & $22.885 \mathrm{a}$ & $25.17 \mathrm{a}$ & $72.45 \mathrm{a}$ & $162.49 \mathrm{a}$ & $0.87 \mathrm{a}$ & $0.42 \mathrm{a}$ & $0.42 \mathrm{a}$ \\
\hline \multirow{2}{*}{ A. nobilis } & $\mathrm{CP}$ & $17.38 \mathrm{a}$ & $5.96 \mathrm{a}$ & $73.35 \mathrm{a}$ & $19.13 b$ & $20.34 b$ & $31.8 \mathrm{~b}$ & $164.24 \mathrm{~b}$ & $0.78 \mathrm{~b}$ & $0.30 \mathrm{~b}$ & $0.35 \mathrm{a}$ \\
\hline & ESP & $13.40 \mathrm{~b}$ & $5.99 \mathrm{a}$ & $74.73 a$ & $22.14 \mathrm{a}$ & $23.88 \mathrm{a}$ & $41.28 \mathrm{a}$ & $434.9 \mathrm{a}$ & $0.84 \mathrm{a}$ & $0.41 \mathrm{a}$ & $0.39 \mathrm{a}$ \\
\hline \multirow{2}{*}{ A. eriophora } & $\mathrm{CP}$ & $11.505 \mathrm{~b}$ & $5.54 \mathrm{a}$ & $72.94 \mathrm{a}$ & $19.877 \mathrm{~b}$ & $21.09 \mathrm{~b}$ & $22.09 b$ & $123.83 \mathrm{~b}$ & $0.81 \mathrm{a}$ & $0.35 \mathrm{a}$ & $0.35 \mathrm{a}$ \\
\hline & ESP & $14.97 \mathrm{a}$ & $4.68 \mathrm{a}$ & $76.9 \mathrm{a}$ & $22.78 \mathrm{a}$ & $25.84 a$ & $33.16 \mathrm{a}$ & $325.55 \mathrm{a}$ & $0.86 \mathrm{a}$ & $0.39 \mathrm{a}$ & $0.42 \mathrm{a}$ \\
\hline \multirow{2}{*}{ M. ricotita } & $\mathrm{CP}$ & $16.32 \mathrm{a}$ & $6.085 \mathrm{a}$ & $71.54 \mathrm{a}$ & $15.74 b$ & $18.77 \mathrm{~b}$ & $46.52 b$ & $47.07 \mathrm{~b}$ & $0.79 \mathrm{a}$ & $0.32 \mathrm{~b}$ & $0.36 \mathrm{a}$ \\
\hline & ESP & $17.82 \mathrm{a}$ & $5.78 \mathrm{a}$ & $73.92 \mathrm{a}$ & $19.57 \mathrm{a}$ & $23.62 \mathrm{a}$ & $90.1 \mathrm{a}$ & $228.31 \mathrm{a}$ & $0.84 \mathrm{a}$ & $0.44 \mathrm{a}$ & $0.39 \mathrm{a}$ \\
\hline \multirow{2}{*}{$\begin{array}{l}\text { An. } \\
\text { haussknechtii }\end{array}$} & $\mathrm{CP}$ & $5.7 \mathrm{~b}$ & $5.90 \mathrm{a}$ & $73.13 \mathrm{a}$ & $12.46 \mathrm{~b}$ & $21.52 \mathrm{~b}$ & $37.99 b$ & $29.2 \mathrm{~b}$ & $0.65 \mathrm{~b}$ & $0.21 \mathrm{~b}$ & $0.29 \mathrm{~b}$ \\
\hline & ESP & $11.26 \mathrm{a}$ & $5.66 \mathrm{a}$ & $74.22 \mathrm{a}$ & $19.90 \mathrm{a}$ & $24.58 \mathrm{a}$ & $55.81 \mathrm{a}$ & $86.16 \mathrm{a}$ & $0.85 a$ & $0.40 \mathrm{a}$ & $0.41 \mathrm{a}$ \\
\hline \multirow{2}{*}{ An. tinctoria } & $\mathrm{CP}$ & $4.06 \mathrm{~b}$ & $5.37 \mathrm{a}$ & $73.45 \mathrm{a}$ & $17.94 \mathrm{~b}$ & $14.46 \mathrm{~b}$ & $23.39 b$ & $22.19 b$ & $0.57 \mathrm{~b}$ & $0.20 \mathrm{~b}$ & $0.26 \mathrm{~b}$ \\
\hline & ESP & $7.49 \mathrm{a}$ & $5.43 \mathrm{a}$ & $68.81 \mathrm{~b}$ & $20.43 \mathrm{a}$ & $23.72 \mathrm{a}$ & $36.77 \mathrm{a}$ & $107.43 \mathrm{a}$ & $0.81 \mathrm{a}$ & $0.336 \mathrm{a}$ & $0.38 \mathrm{a}$ \\
\hline
\end{tabular}


Table 8. Genetic variation statistics revealed through ISSR marker comparing the control plants (CP) and early selected plants (ESP), and pooled of studied species

\begin{tabular}{|c|c|c|c|c|c|}
\hline Species & $\mathrm{CP} / \mathrm{ESP}$ & $\mathrm{Na}$ & $N p$ & $\mathrm{He}$ & $\mathrm{P} \%$ \\
\hline \multirow{3}{*}{ A. millefolium } & $\mathrm{CP}$ & 17 & 0 & 0.077 & 19.61 \\
\hline & ESP & 22 & 0 & 0.118 & 33.33 \\
\hline & pooled & 26 & 0 & 0.126 & 43.14 \\
\hline \multirow{3}{*}{ A. fillipendulla } & $\mathrm{CP}$ & 9 & 0 & 0.057 & 13.73 \\
\hline & ESP & 17 & 1 & 0.065 & 15.69 \\
\hline & pooled & 17 & 1 & 0.111 & 29.41 \\
\hline \multirow{3}{*}{ A. biebersteinii } & $\mathrm{CP}$ & 19 & 1 & 0.078 & 23.53 \\
\hline & ESP & 18 & 1 & 0.085 & 23.53 \\
\hline & pooled & 26 & 2 & 0.107 & 41.18 \\
\hline \multirow{3}{*}{ A. nobilis } & $\mathrm{CP}$ & 19 & 0 & 0.101 & 27.45 \\
\hline & ESP & 19 & 1 & 0.108 & 27.45 \\
\hline & pooled & 25 & 1 & 0.121 & 41.18 \\
\hline \multirow{3}{*}{ A. eriophora } & $\mathrm{CP}$ & 11 & 0 & 0.027 & 11.13 \\
\hline & ESP & 16 & 2 & 0.027 & 12.94 \\
\hline & pooled & 20 & 2 & 0.106 & 25.49 \\
\hline \multirow{3}{*}{ M. ricotita } & $\mathrm{CP}$ & 28 & 0 & 0.032 & 7.84 \\
\hline & ESP & 28 & 0 & 0.081 & 19.61 \\
\hline & pooled & 32 & 1 & 0.139 & 33.33 \\
\hline \multirow{3}{*}{$\begin{array}{l}\text { An. } \\
\text { haussknechtii }\end{array}$} & $\mathrm{CP}$ & 33 & 0 & 0.116 & 31.37 \\
\hline & ESP & 28 & 0 & 0.120 & 31.37 \\
\hline & pooled & 33 & 0 & 0.184 & 47.06 \\
\hline \multirow{3}{*}{ An. tinctoria } & $\mathrm{CP}$ & 18 & 0 & 0.028 & 13.53 \\
\hline & ESP & 29 & 0 & 0.029 & 13.53 \\
\hline & pooled & 29 & 0 & 0.089 & 21.57 \\
\hline
\end{tabular}

$\mathrm{Na}$, mean number of alleles; $N p$, number of private alleles; $\mathrm{He}$, expected heterozygosity; $\mathrm{P} \%$, percentage of polymorphic loci.

correlates with early maturity. Early flowering plants are advantageous compared to plants with a later flowering time and longer vegetative periods (BODNER et al., 2015).

To cope with the challenges caused by abiotic stresses, plants have developed several strategies. One of these defense mechanisms against osmotic stress is to collect organic osmolytes (such as proline and soluble sugars) in the cytoplasm to maintain the plant water potential during drought stress conditions. Results of the physiological traits in CP versus ESP in a field under rainfed conditions indicated a significantly higher amount of soluble sugars and proline content in ESP in almost all species (except $A$. fillipendulla). As observed in $A$. vermicularis, A. eriophora, A. tenuifolia (SALEHI Shanjani et al., 2015; Mohammadpour et al., 2015), An. tinctoria, Tripleurospermum servanes, M. recutita and Tanacetum parthenium (SALEHI SHANJANI et al., 2020), Kochia sieversiana (YANG et al., 2007), and in Zea mays (BADR et al., 2020), the proline and soluble sugar content increased with increasing stress. Effects of drought stress on proline accumulation among several crops implied that the rate of its accumulation and utilization was remarkably higher in the drought-tolerant cultivar. Proline is a highly water-soluble amino acid that is accumulated in leaves of many plant species grown in arid environments. Proline functions as a protection for membranes and proteins against the adverse effects of drought, high concentration of inorganic ions, and temperature extremes. Besides, it is applicable as a protein-compatible hydrotrope and a hydroxyl radical scavenger (HAYAT et al., 2012). The higher amount of proline and soluble sugar in the ESP suggested that the plants were more efficient than $\mathrm{CP}$ in dealing with drought conditions.

Results of the present study indicated that the amount of chlorophyll a, chlorophyll b, and carotenoids were significantly higher in ESP of A. biebersteinii, A. nobilis, An. haussknechtii and An. tinctoria species. The effects of drought on chlorophyll and carotenoid contents were inspected in several medicinal plants; in A. vermicularis and $A$. tenuifolia amount of carotenoid content increased but the amount of chlorophyll content decreased (Mohammadpour et al., 2015; Salehi Shanjani et al., 2014). Chlorophyll maintenance plays the main role in photosynthesis in water-deficient conditions. Carotenoids are essential in scavenging singlet oxygen; hence, their comparative amount in a plant determines its relative tolerance. With increasing the drought level, these pigments were reduced, and the varieties which showed maximum chlorophyll amounts in water-deficient conditions were considered drought-tolerant (KAPOOR et al., 2020).

A possible approach for variety development is to assess the genetic diversity of germplasm, which can provide a platform for the selection of superior genotypes as parents in programs of crop improvement breeding (NAchimuthu et al., 2015). The focus of the study was to compare the genetic variation of $\mathrm{CP}$ and ESP groups since domestication or artificial selection only supports a few alleles that result in a higher frequency of selected alleles. Therefore, in comparison with the diversity in wild, domestication reduces genetic diversity (BHANDARI et al., 2017). Still, average levels of genetic variation within the CP or ESP groups of the studied species are not significantly different. Results of the current study signified added genetic variation within CP and ESP groups (51\%) than between the groups $(21 \%)$ or between studied species $(28 \%)$. The genetic correlation among the genotypes is related to taxon even though AMOVA showed a partial differentiation between CP and ESP (21\%). The present findings are compatible with previous studies on Anthemis, Achillea, and Matricaria species which showed more genetic variation within populations than between species (GHARIBI et al., 2011; FARAJPOUR et al., 2012; EBRAHIMI 


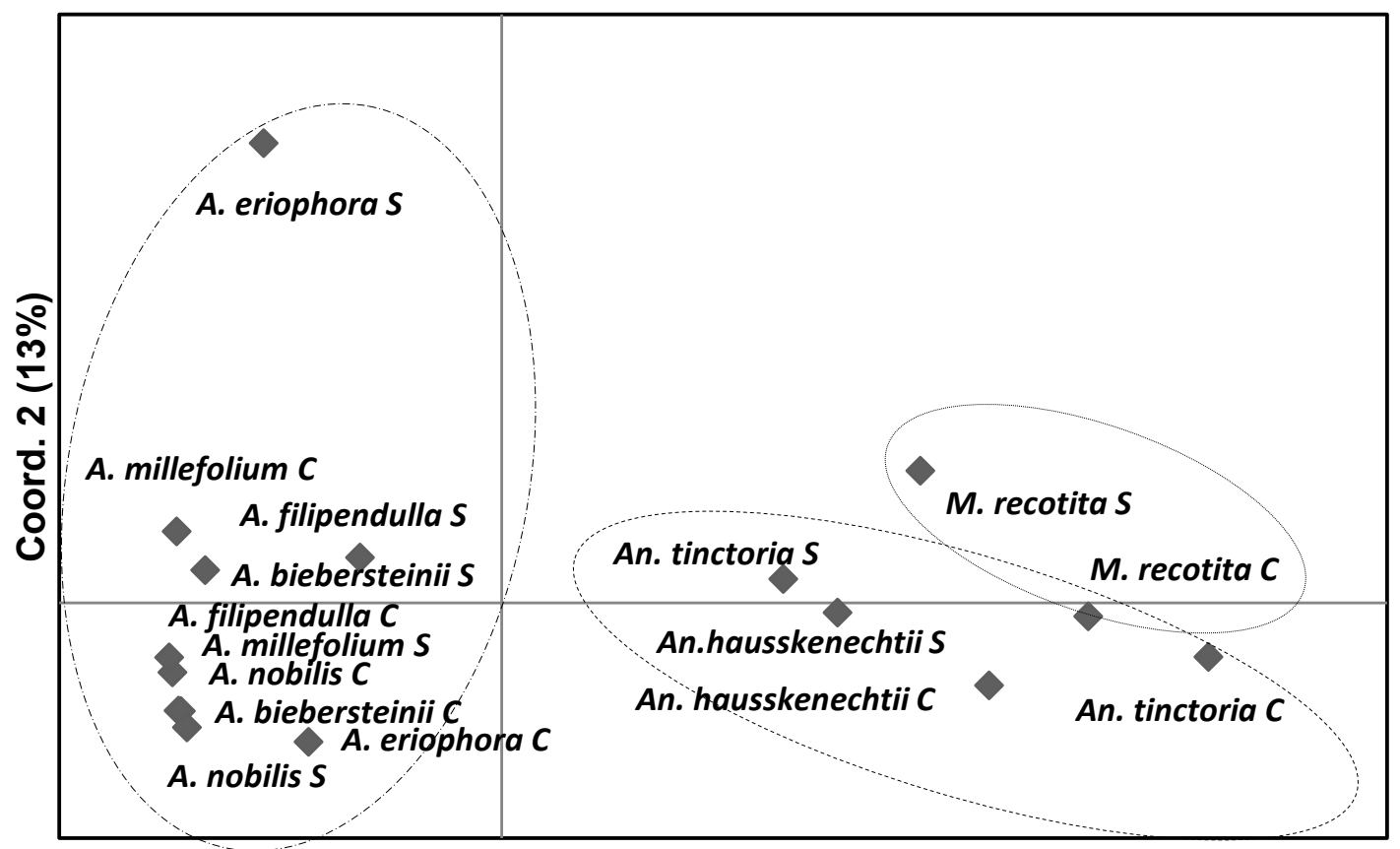

Coord. 1 (61\%)

Fig. 2. Scatter diagram based on ISSR marker for the control (with suffix C) and early selected (germinated at osmotic potential -0.6 MPa, with suffix S) genotypes of studied species.

et al., 2012) and on other species that are characterized by high genetic variation within populations (GODT and HAMRICK, 2001).

It was concluded that survived seedlings at drought conditions may expose moderate-to-high viability with an additive gene effect across environments. The selection of tolerating individuals at the seedling stage represents a possible promising strategy to obtain higher drought tolerance plants under rainfed conditions. This information could be utilized for designing an effective breeding strategy for developing a variety of higher producing yields under drought stress and usefully applicable in a program of yarrow and chamomile rehabilitation and reintroducing of Anthemis, Achillea, and Matricaria species.

\section{References}

Ahmed, H., Khan, A.S., Khan, S.H., Kashif, M., 2017. Genome wide allelic pattern and genetic diversity of spring wheat genotypes through SSR markers. International Journal of Agriculture and Biology, 19: 1559-1565. DOI: 10.17957/IJAB/15.0463

Ahmed, H., Sajuad, M., Minguu, L., Abubakkar, M., Rizwan, M., Maqsood, R., Khan, S., 2019. Selection criteria for drought-tolerant bread wheat genotypes at seedling stage. Sustainability, 11: 1-17.

Almeselmani, M., Abdullah, F., Hareri, F., NaAesan, M., Ammar, M.A., Zuher Kanbar, O., SAud, A.A., 2011. Effect of drought on different physiological characters and yield component in different varieties of Syrian durum wheat. Journal of Agricultural Science, 3: 127-133. DOI: $10.5539 /$ jas.v3n3p127
ArJenaki, F., JabBari, A.R., Morshedi, A., 2012. Evaluation of drought stress on relative water content, chlorophyll content and mineral elements of wheat (Triticum aestivum L.) varieties. International Journal of Agriculture and Crop Science, 4: 726-729.

Badr, A., El-Shazly, H.H., Tarawneh, R.A., Börner, A., 2020. Screening for drought tolerance in maize (Zea mays L.) germplasm using germination and seedling traits under simulated drought conditions. Plants, 9 (5): 565. https://doi.org/10.3390/plants9050565

Bates, L.S., Waldren, R.P., Teare, I.D., 1973. Rapid determination of free proline for water- stress studies. Plant and Soil, 39: 205-207. https://doi.org/10.1007/ BF00018060

Bilal, M., Rashid, R.M., Rehman, S.U., Igbal, F., Ahmed, J., ABID, M.A., Ahmed, Z., Hayat, A., 2015. Evaluation of wheat genotypes for drought tolerance. Journal of Green Physiology, Genetics and Genomics, 1: 11-21.

Bodner, G., NAKHFOROOSH,A., KaUl, H.P., 2015. Management of crop water under drought: A review. Agronomy for Sustainable Development, 35: 401-442. https://doi. org/10.1007/s13593-015-0283-4

BRADFORD, M.M., 1976. A rapid and sensitive method for the quantitation of microgram quantities of protein utilizing the principle of protein-dye binding. Annals of Biochemistry, 72:248-254. https://doi.org/10.1016/00032697(76)90527-3

Datta, J., Mondal, T., Banerjee, A., Mondal, N., 2011. Assessment of drought tolerance of selected wheat cultivars under laboratory condition. Journal of Agricaltural Technology, 7: 383-393.

Ebrahimi, M., Farajpour, M., Rahimmalek, M., 2012. Inter- and intra-specific genetic diversity of Iranian yarrow species Achillea santolina and Achillea tenuifolia 
based on ISSR and RAPD markers. Genetics and Molecular Research, 27: 2855-2861. (In Persian). https:// doi.org/10.4238/2012.August.27.1

Emadodin, I., Reinsch, T., Taube, F., 2019. Drought and desertification in Iran. Hydrology, 6: 12. https://doi. org/10.3390/hydrology6030066

Fahad, S., BajWA, A.A., NAZir, U., AnJum, S.A., Farooq, A., Zohaib, A., Sadia, S., Nasim, W., Adkins, S., Saud, S., Ihsan, M.Z., Alharby, H., Wu, C., Wang, D., Huang, J., 2017. Crop production under drought and heat stress: plant responses and management options. Frontiers in Plant Science, 8: 1147. https://doi.org/10.3389/fpls.2017.01147

Farajpour, M., Ebrahimi, M., Amiri, R., Golzari, R., SANJari, S., 2012. Assessment OF Genetic DIVERSITY IN ACHILLEA MILLEFOLIUM ACCESSIONS FROM IRAN USING ISSR MARKER. Biochemical Systematics and Ecology, 43: 73-79. https://doi.org/10.1016/j. bse.2012.02.017

Fu, J., Huang, B., 2001. Involvement of antioxidants and lipid peroxidation in the adaptation of two cool-season grasses to localized drought stress. Environmental and Experimantal Botany, 59: 105-114. https://doi. org/10.1016/S0098-8472(00)00084-8

Ghani, A., Azizi, M., Tehranifar, A., 2009. Response of Achillea species to drought stress induce by polyethylene glycol in germination stage. Iranian Journal of Medicinal Aromatic Plants, 25: 261-271. (In Persian). DOI: 10.22092/ijmapr.2009.7259

Gharibi, S., RahimmaleK, M., Mirlohi, A., Majidi, M.M., SAYed-TabatabaeI, B., 2011. Assessment of genetic diversity in Achillea millefolium subsp. millefolium and Achillea millefolium subsp. elbursensis using morphological and ISSR markers. Journal of Medicinal Plants Research, 5: 2413-2423.

Godt, M.J.W., Hamrick, J., 2001. Genetic diversity in rare southeastern plants. Natural Areas Journal, 21: 61-70.

Hayat, S., Hayat, Q., Alyemeni, M., Wani, D.A., Pichtel, J., Ahmad, A., 2012. Role of proline under changing environment: A review. Plant Signalling and Behavior, 7: 1456-1466. https://doi.org/10.4161/psb.21949

Kapoor, D., Bhardwaj, S., Landi, M., Sharma, A., Ramakrishnan, M., Sharma, A., 2020. The impact of drought in plant metabolism: How to exploit tolerance mechanisms to increase crop production. Applied Science, 10: 5692. https://doi.org/10.3390/app10165692

KoOYers, N.J., 2015. The evolution of drought escape and avoidance in natural herbaceous populations. Plant Science, 234: 155-162. https://doi.org/10.1016/j. plantsci.2015.02.012

Li, H., Li, X., Zhang, D., LiU, H., GuAn, K., 2013. Effects of drought stress on the seed germination and early seedling growth of the endemic desert plant Eremosparton songoricum (Fabaceae). EXCLI Journal, 12: 89-101.

LichtenthaleR, H.K., 1987. Chlorophylls and carotenoids: pigments of photosynthetic biomembranes. Methods of Enzymology, 148: 350-382. https://doi.org/10.1016/00766879(87)48036-1

Lobell, D.B., Roberts, M.J., Schlenker, W., Braun, N.L., Little, B.B., Rejesus, R.M., HAmmer, G.L., 2014. Greater sensitivity to drought accompanies maize yield increase in the U.S.-Midwest. Science, 344: 516-519. DOI: $10.1126 /$ science. 1251423
Mohammadpour, M., Negahban, M., Saeedfar, S., Salehi ShanJani, P., JAVADI, H., 2015. Effect of drought stress on some of the biochemical characteristics of three Achillea populations (A. vermicularis). Russian Journal of Biological Research, 4: 68-80. DOI: 10.13187/ ejbr.2015.4.68

Monfared, M.A., Samsampour, D., Sharifi-Sirchi, G.R., SADEGHI, F., 2018. Assessment of genetic diversity in Salvadora persica L. based on inter simple sequence repeat (ISSR) genetic marker. Journal of Genetic Engineering and Biotechnology, 16: 661-667. https://doi. org/10.1016/j.jgeb.2018.04.005

Nachimuthu, V.V., Muthurajan, R., Duraialaguraja, S., Sivakami, R., Pandian, B.A., Ponniah, G., Gunasekaran, K., Swaminathan, M., Suji, K.K., SabarIAPPAN, R., 2015. Analysis of population structure and genetic diversity in rice germplasm using SSR markers: An initiative towards association mapping of agronomic traits in Oryza sativa. Rice, 8: 30. https://doi.org/10.1186/ s12284-015-0062-5

NeI, M., 1978. Estimation of average heterozygosity and genetic distance from a small number of individuals. Genetics, 89: 583-590.

Parmesan, C., Yohe, G., 2003. A globally coherent fingerprint of climate change impacts across natural systems. Nature, 421: 37-42. https://doi.org/10.1038/ nature 01286

Peakall, R., Smouse, P.E., 2006. GenaleX 6: Genetic Analysis in Excel. Population genetic software for teaching and research. Molecular Ecology Notes, 6: 288295.

QARI, S., 2017. DETECTION OF GENETIC DIVERSITY AMONG SOME SPECIES OF ANTHEMIS L. (Asteraceae) IN SAUdi Arabia BY USING RAPD-PCR ANALYSIS. African Journal of Plant Science, 11: 92-98. DOI: 10.5897/AJPS2017.1523

RohlF, J., 2004. NTSYS-PC Version 2.11T. Numerical Taxonomy and Multivariate Analysis System. Applied Bioestastistics, Inc.

Salehi Shanjani, P., Izadpanah, M., Falah Hoseini, L., Ramezani Yeganeh, M., Rasoulzadeh, L., Kavandi, A., Sardabi, F., Pahlevani, M.R., Amirkhani, M., Seyedian, S.E., 2015. Comparison of drought on pigments, osmotic adjustment and antioxidant enzymes in different wild accessions of Anthemis tinctoria and Tripleurospermum servanes of Natural Resources Gene Bank of Iran. Journal of Plant Research (Iranian Journal of Biology), 28: 126-139. (In Persian).

Salehi Shanjani, P., Izadpanah, M., Mohamadpour, M.R., 2014. Effects of water stress on germination of yarrow populations from different bioclimatic zones in Iran. Plant Breeding and Seed Science, 68: 39-54.

Salehi Shanjani, P., Rasoulzadeh, L., Falah Hoseini, L., Ramezani Yeganeh, M., Amirkhani, M., Pahlavani, M.R., Seyedian, S.E., Javadi, H., 2020. Morphophysiological responses of four chamomile species to rainfed conditions and drought stress under greenhouse conditions. Iranian Journal of Rangelands and Forests Plant Breeding and Genetic Research, 28: 51-65. (In Persian).

Sherrard, M., Maherali, H., 2006. The adaptive significance of drought escape in Avena barbata, an annual grass. Evolution, 60: 2478-89. https://doi. $\operatorname{org} / 10.1111 / \mathrm{j} .0014-3820.2006 . t b 01883 . x$ 
Sun, Y., Du, X., Zhang, W., Sun, L., Li, R., 2011. Seed germination and physiological characteristics of Amaranthus mangostanus L. under drought stress. Advanced Materials Research, 183-185: 1071-1074. DOI: 10.4028/www.scientific.net/amr.183-185.1071

Suzuki, N., Rivero, R.M., Shulaev, V., Blumwald, E., MitTLER, R., 2014. Abiotic and biotic stress combinations. New Phytologist, 203: 32-43. https://doi.org/10.1111/ nph.12797

Wang, F.Z., Wang, Q.B., Kwon, S.Y., KwaK, S.S., Su, W.A., 2005. Enhanced drought tolerance of transgenic rice plants expressing a peamanganese superoxide dismutase. Journal of Plant Physiology, 162: 465-472. DOI: 10.1016/j.jplph.2004.09.009

Yamasaki, S., Dillendirg, L., 1999. Measurements of leaf relative water content in Araucaria angustifolia. Revista Brasilleira de Fisiologia Vegetal, 11: 69-75.
Yang, C., Chong, J., Li, C., Kim, C., Shi, D., Wang, D., 2007. Osmotic adjustment and ion balance traits of an alkali resistant halophyte Kochia sieversiana during adaptation to salt and alkali conditions. Plant and Soil, 294: 263276. https://doi.org/10.1007/s11104-007-9251-3

Yemm, E.W., Willis, A.J., 1954. The estimation of carbohydrates in plant extracts by anthrone. Biochemical Journal, 57: 508-514. https://doi.org/10.1042/bj0570508

ZietKiewicz, E., Rafalski, J., Labuda, D., 1994. Genome fingerprinting by simple sequence repeat (SSR)-anchored polymerase chain reaction amplification. Genomics, 20: 176-183. DOI: 10.1006/geno.1994.1151

Received August 29, 2021 Accepted December 1, 2021 